\title{
JEOPARDIZING REFORM IN NEW YORK CITY
}

\author{
BY DR. WM. H. ALLEN \\ New York City
}

$I^{N}$ $\mathrm{N}$ the July issue of the National Municipal Review, Robert S. Binkerd, secretary of the New York city club challenged the fairness and accuracy of statements made in an article by me entitled "Tuberose Obstacles to Reform in New York City." 2

By confronting Mr. Binkerd's statements with official records students of municipal affairs will be helped to see in what jeopardy municipal reform in New York City is being placed by the attitude of recognized - even self-admitted-leaders of municipal reform.

The first instance of alleged unfairness and inaccuracy relates to a five year lease of private property by the public service commission which was cited by me as unnecessary, because "at the time when the mayor and the chamberlain might have been looking at submitted evidence to show how and where the public service commission could be satisfactorily housed in vacant city-owned property, they were listening to the commission's reasons for wanting to lease private property."

To discredit this statement Mr. Binkerd wrote: "The city authorities had not the slightest control over the lease made by the public service commission. . . . They attempted to secure a postponement . . . in an endeavor to find cheaper quarters. The responsibility and blame for this lease, if there be any, is surely upon the commission and not upon the city government."

In comparing these statements with the official facts that follow will readers bear in mind that $\mathrm{Mr}$. Binkerd is secretary of the city club of New York, which organization says of itself in the charities directory for 1916 that its purpose is "securing permanent good government for the the City of New York . . . a non-partisan civic organization watching the various branches of the municipal government."

Is it unnatural that the general home public or out of town students of public affairs take it for granted, first, that Mr. Binkerd will not speak unless he knows, and secondly that what he thinks he knows is correct?

Can anyone doubt that public officials will come to believe that it is safe to go as far away from or stay as near self-extenuation as the city club will publicly approve?

Now for the official record.

January 21, 1916, the chairman of the public service commission wrote to the bridge commissioner-representative of the sinking fund commis-

${ }^{1}$ Sse vol, v, p. 427.

2 See vol. v, p. 419. 
sion of which the mayor, chamberlain and comptroller are membersasking for space in the municipal building. Later the chairman and other officers of the public service commission went through the municipal building and other city-owned buildings to see where space might be found. On this tour President Straus was heard to remark: "If this were a private building we would find space without spending city money on a private lease."

Later President Straus wrote to the institute for public service: "The commission has sent a letter to the bridge commissioner making such request"-i.e., "suggesting the possibility of the readjustment of space in the municipal building so as to afford space for the public service commission."

On February 16, 1916, the institute submitted to Chamberlain Bruère evidence showing how vastly more space could be obtained in the building than the public service commission needed. We kept an appointment at his office made by him, but which he failed to keep. We could not reach him or the mayor by telephone because they were closeted with one of the public service commissioners. Postponement of the signing of the lease was secured by city officers, and the lease was not completed until Mayor Mitchel telephoned that he would not ask the commission to wait longer. He did release the commission from its pledge before either he or the chamberlain looked at evidence submitted at their request showing that the lease was unnecessary.

All these facts had been published in the newspapers before Mr. Binkerd wrote his letter to the National Municipal Review, as they were later testified to before the Thompson investigating committee and again published in the newspapers.

There is only one other point regarding which Mr. Binkerd challenged my fairness and accuracy. He wrote: "Dr. Allen states that the fire prevention work had been going for years under Mayor Gaynor. The bureau was established in 1911 but constituted one of the glaring weak spots of Mayor Gaynor's administration. The appointments of fire prevention inspectors were practically parceled out to the leaders of Tammany hall. . . " The implication is that my statement was untrue and that fire prevention work had not been going on for years under Mayor Gaynor.

In the published report of the fire department for 1912 appear these facts: arrests for arson 64; convictions for arson 40 ; pending arson cases 22 ; total inspections 132,601 ; orders served 18,684 , of which 128 called for installation of sprinkler systems, 603 for fire escapes, and the remainder for additional stairways, adequate exits, fireproofing of stairways, removal of rubbish, prevention of smoking where such smoking constituted a menace to life and property; summonses in criminal proceedings 316 ; conviction for violation of the fire prevention law 154; original inspections 
of theatres, moving picture shows, dance halls, boxing clubs, etc. 3,402; reinspections 14,083; dangerous conditions remedied in 1,503 instances, etc.

On review of this year's work the budget was voted by a fusion majority of the board of estimate and apportionment, including Comptroller Prendergast, Borough President McAneny, and now Mayor Mitchel, giving the fire prevention bureau $\$ 255,000$ for 1913 .

Would you have judged this from the facts stated by Mr. Binkerd? It is true that appointments were "practically parceled out to the leaders of Tammany hall." It is also true that infinitely more headway would have been made by those who lamented that parceling out if they had shown how the work of fire prevention was suffering, instead of confining their attention to the political motive of the appointing power.

\section{MR. BINKERD'S COMMENT}

Without discussing the practicability of Dr. Allen's plans for economizing space in the Municipal Building, the fact that the city authorities conceivably could have offered space to the Public Service Commission does not alter the fact that the commission is responsible for the lease which it entered into. In one breath $\mathrm{Dr}$. Allen criticizes the mayor and the chamberlain for "listening to the commission's reasons for wanting to lease private property." In the next breath he criticizes me for stating that the commission is responsible for what it had full legal power to do, and what he admits it wanted to do!

As to the bureau of fire prevention, the fact that it was established in 1911, received public money, and engaged in some activity, does not for one moment disprove that the present city administration inherited in that bureau a welter of inefficiency, the removal of which put fire prevention work soundly on its feet for the first time.

As for those delightful personalities which enliven Dr. Allen's argument, ending in the conclusion that I constitute a jeopardy to reform, I can only say that a jeopard cannot change his spots.

RoBert S. Binkerd. 